\title{
Geçmişten Geleceğe Akdeniz Ülkelerinde Turizm
}

\section{Tourism in Mediterranean Countries-From Past to Future}

\author{
Volkan ZOĞAL ${ }^{1}$ (D), Füsun BAYKAL ${ }^{1}$ (10) \\ ${ }^{1}$ Ege Üniversitesi, Edebiyat Fakültesi, Coğrafya Bölümü, İzmir, Türkiye
}

ORCID: V.Z. 0000-0003-0059-1958; F.B. 0000-0002-4599-4235

\section{öz}

Uluslararası turizm hareketlerinde geçmişten bugüne en önemli merkez Avrupa Kıtası olmuştur. Kıtanın Akdeniz kıyı ülkeleri ise turizmdeki bugünkü gelişmişlik düzeyini ve dünyada söz sahibi oluşunu, başta coğrafi konum olmak üzere tarihsel derinlik, doğal ve kültürel çekiciliklere borçludur. Ayrıca nitelikli hizmet, etkili tanıtım, doğru pazarlama ve yüksek talep de önemli birer faktördür. Bu çalışma, Akdeniz'de turist hareketliliğini hem tarihsel süreçte hem de mekânsal düzlemde ele almaktadır. Amaç, Akdeniz'in dünya turizminde yüzyıllardır eskimeyen öneminin nedenlerine inmek ve günümüzdeki sonuçlarını ülkeler bazında karşılaştırmaktır. Araştırmanın yaklaşımı ve yöntemi, nitel ve nicel veriler kullanarak hem bir tematik derleme hem de karşılaştırmalar yoluyla ilişkisel analiz yapmaya dayalıdır. Bulgularda Akdeniz turizminde geçmiş yüzyıllarda turist hareketliliğindeki dinamikler ile bugünün turistini çeken faktörlerin aynı olmadığı ortaya çıkmıştır. Geçmişte kültür turistlerinin ilgisi söz konusuyken, bugünün müşterileri ise çoğunlukla deniz-kumgüneş turistleridir. Ancak güncel toplumsal olaylar ve teknolojik gelişmeler, turistlerin beklentilerini de hızla değiştirmekte ve yeni turizm türlerini ortaya çıkarmaktadır. Sonuç olarak Akdeniz Havzası'nın uluslararası turizmdeki geleceği, iç faktörlerin baskısıyla şekillenecek gibi görünüyorsa da dış faktörlerin (küresel iklim değişikliği, salgın hastalıklar, uluslararası göçler, politikalar, terörizm, teknolojik gelişimler gibi) daha güçlü bir belirleyici ve yönlendirici olabileceği ileri sürülebilir.

Anahtar kelimeler: Turizm, eşitsizlik, Akdeniz

\section{ABSTRACT}

Europe has been the most important center of international tourism from the past to the present. The continent's Mediterranean coastal countries, in particular, owe their present level of tourism to their historical depth, natural and cultural attractions, and geographical location. In addition, qualified services, effective promotion, correct marketing, and high demand are also important factors. In this study, we discuss tourist mobility in the Mediterranean in both historical and spatial terms to examine the reasons for the importance of the Mediterranean in world tourism and compare current results across countries. The research approach and methods comprise a thematic review and comparison using qualitative and quantitative data. The findings clearly indicate that tourist activities in Mediterranean countries have changed over the centuries. Cultural tourism was the preferred activity in the past, but today's customers are mostly sea-sand-sun seekers. However, social change and technological developments have altered tourists' expectations and revealed new types of tourism. As a result, although the future of international tourism in Mediterranean countries seems to be shaped by internal factors, it could be argued that external factors such as global climate change, epidemics, international migration policies, terrorism, and technological developments may be stronger determinants.

Keywords: Tourism, Inequality, and Mediterranean

Başvuru/Submitted: 21.09.2020 • Revizyon Talebi/Revision Requested: 21.11.2020 • Son Revizyon/Last Revision Received: 01.12 .2020 • Kabul/Accepted: 04.12.2020 - Online Yayın/Published Online: 25.12.2020

Sorumlu yazar/Corresponding author: Volkan ZOĞAL / volkan.zogal@ege.edu.tr

Atıf/Citation: Zogal, V., \& Baykal, F. (2020). Geçmişten geleceğe Akdeniz ülkelerinde turizm. Cografya Dergisi, 41, 255-270.

https://doi.org/10.26650/JGEOG2020-0071 


\section{EXTENDED ABSTRACT}

The Mediterranean Basin is one of the oldest settlements and prominent centers of world civilization and is also a region where tourism emerged and developed. Although not exactly matching today's tourist phenomena, the region has been at the center of the first tourist movements since prehistoric times and remains the world's largest tourist destination today. This study evaluates the movement of tourists in Mediterranean countries to explain their causes and make predictions for the future. The research approach and method comprise a thematic review and comparison using qualitative and quantitative data. The article begins by charting the development of tourism from antiquity to the medieval period, then from the Renaissance to the end of the industrial revolution, before examining the twentieth century. Fundamental questions such as where, why, and how are answered using a geographical approach.

Tourism-related developments in the region are divided into certain periods based on the turning points of history. The trips attended by the ancient Greeks and the noble and wealthy Romans for culture, art, religion, sports, and entertainment were the first forms of tourism. During the first half of the Middle Ages, religious movements made visits to sacred cities in the Mediterranean and made their mark on tourism. During the Renaissance, travels were made for trade, entertainment, and exploration. The Grand Tour, performed by princes, nobles, diplomats, artists, students, and scientists in the $16^{\text {th }}$ and $18^{\text {th }}$ centuries, was the earliest form of modern tourism. Paris, Marseille, Nice, Geneva, Turin, Genoa, Rome, Naples, Florence, and Venice were the main destinations of this tour. Toward the end of the $18^{\text {th }}$ century, resorts and spa towns (such as Nice and Côte d'Azur) began to be established; however, travel for tourist purposes was largely an activity of the wealthy and educated minority class. The industrial revolution and the construction of railways during the $19^{\text {th }}$ century completely changed the direction of tourism and travel in Europe and the Mediterranean. The romance of the Eastern Mediterranean aroused great curiosity in the coastal countries during this century. The Eastern Express train journey began in Paris and was an important driving force of the flow of tourists between west and east. During this century, it also became fashionable to spend the winter months in Italy, Sicily, and Corsica. The period from the first quarter of the $19^{\text {th }}$ century to the middle of the $20^{\text {th }}$ century witnessed the emergence of modern tourism. During this period, tourism evolved into a large economic sector with its own infrastructure, and the most striking developments were witnessed in the Mediterranean. After the 1960s, tourism grew massively, and France, Spain, and Italy became the stars of Mediterranean mass tourism.

The Mediterranean Basin is the center of international tourism today, as it was in the past. France, Spain, Italy, and Turkey are the foremost visited countries followed by Greece, Croatia, Morocco, and Egypt. Today, unique attractions are no longer enough. Tourists' expectations and holiday requirements have changed enormously. Service quality, security, and originality have become the most prominent factors affecting each country's competitiveness. Generally, economic and political factors control them all. During the first quarter of the $21^{\text {st }}$ century, developments in information and communication technologies led to a new breaking point in the history of tourism and accelerated the transition to the postmodern tourism era. The foundation of this new era was inlaid with internet technology. The rapid rise of sharing economy platforms has deeply affected the traditional structure of tourism and Mediterranean countries have been the most affected by this new phenomenon. Also, the COVID-19 pandemic began in December 2019 and spread worldwide in a short time bringing tourists' movements to a halt. The pandemic has deeply affected all countries in the region, especially Italy, Spain, France, and Turkey. This unexpected disaster frustrated all the plans and predictions about the future of tourism. In the coming years, it is expected that economic crises, global climate change, environmental pollution, and technological innovations will continue to affect the development of tourism. Due to its geographical and geopolitical location, the Mediterranean Basin will remain one of the regions most positively and negatively affected by these international developments. 


\section{GİRİŞ: Akdeniz Ülkeleri, Amaç, Yöntem ve Tasarım}

Dünyanın en eski yerleşim alanlarından ve önde gelen uygarlık merkezlerinden biri olan Akdeniz Havzası, aynı zamanda turizmin doğduğu, geliştiği ve bugün de dünyanın en büyük destinasyonu hâline geldiği bir bölgedir. Akdeniz, yaklaşık 2,5 milyon $\mathrm{km}^{2}$ yüzölçümüne sahiptir (Tixeront, 1969, s.61). Doğuda Asya, kuzeyde Avrupa ve güneyde Afrika olmak üzere üç kıtanın kıyılarıyla çevrelenmiş bir iç denizdir. Batıda Cebelitarık Boğazı ile Atlas Okyanusu'na bağlanmıştır (Şekil 1).

Akdeniz'e kıyısı olan toplam 23 ülke vardır: Íspanya, Fransa, Monaco, Italya, Slovenya, Hırvatistan, Bosna-Hersek, Karadağ, Arnavutluk, Yunanistan, Türkiye, Suriye, Lübnan, İsrail, Filistin Yönetimi, Mısır, Libya, Tunus, Cezayir, Fas, Malta, Kuzey Kıbrıs Türk Cumhuriyeti ve Güney Kıbrıs Rum Yönetimi (Şekil 1). Türkiye, gerek matematiksel gerekse özel ve jeopolitik konumu ile bir Doğu Akdeniz, hatta tam anlamiyla bir Kuzeydoğu Akdeniz ülkesidir. Çünkü Türkiye, Trakya üzerinden Balkan Yarımadası ve dolayısıyla Güneydoğu Avrupa ile fiziksel ve kültürel anlamda bir birlikteliğe sahiptir. Türkiye'nin 8333 km'lik kıyı bandının, \%20,34'ü Karadeniz, \%11,20'si Marmara, \%33,66's1 Ege ve \%20,07'si Akdeniz kıyılarına aittir. Türkiye, Akdeniz Havzası kıyı uzunluğundan (46 bin km) yaklaşı \%12 pay almaktadır (Coudert, 1996, s.35).

Akdeniz Havzası'nda Misır, Fenike, Aka ve Roma gibi büyük antik uygarlıklar ortaya çıkmış, Orta Çağ'da Bizans ve daha sonra Osmanlı İmparatorluğu, güncel olarak da birçok devlet bu havzada varlık göstermiştir. Tarihsel süreçte politik, askeri, ticari, sosyo-kültürel ve turizm amaçlı gelişmeler, havzayı her zaman hareketli bir ortam yapmıştır. Akdeniz, ilk turistik hareketlerin başlangıcında ve merkezinde yer aldığı gibi bugün de odak bölge olma konumunu hâlâ sürdürmektedir. Dolayısıyla, turizm tarihinin temeli Akdeniz'de atılmış, yapı taşları burada örülmüş ve yaklaşık beş bin yıllık süreç burada yaşanmıştır. $\mathrm{Bu}$ uzun süreçte Akdeniz ülkelerinde turizmle bağlantılı doğal, kültürel çekicilikler ve hizmetlerin kodunu çözebilmek için üç aşamalı yaklaşım önerilmektedir: (i) tarihsel Akdeniz ortamı içinde geçmişteki turizm, (ii) bu ortamın değişmekte olduğu günümüzdeki turizm, (iii) geleceğin turizmi (Selwyn, 2000, s.241).

$\mathrm{Bu}$ çalışmanın amacı, Akdeniz'deki turizm hareketlerini geçmişten bugüne değerlendirmek, turizmde dünya çapındaki eskimeyen önemin nedenlerini ortaya koymak ve gelecek hakkındaki görüşlere ve öngörülere yer vermektir. Araştırmanın yaklaşımı ve yöntemi, nitel ve nicel veriler kullanarak hem tematik bir derleme hem de dönemsel ve sayısal karşılaştırmalar yapmaya dayalıdır. Bu yolda ilerleyen çalışma, aynı zamanda zaman-mekân düzleminde bir ilişkisel analiz formatına da bürünmüştür. Makalenin tasarımında turizmle ilgili gelişmeler, yirmi birinci yüzyıla (Milenyum) gelinceye kadar üç dönemde ele alınmıştır: (i) ilk turizm hareketleri kapsamında ilkçağ ve ortaçağ dönemi; (ii) arkasından turizmde büyük gelişmelere ilk adımların atıldığı Rönesans'tan sanayi devrimi sonuna kadar olan dönem; (iii) son olarak da turizmin gerçek anlamda zirve yaptığı yirminci yüzyıl dönemi olarak ele alınmış, coğrafi

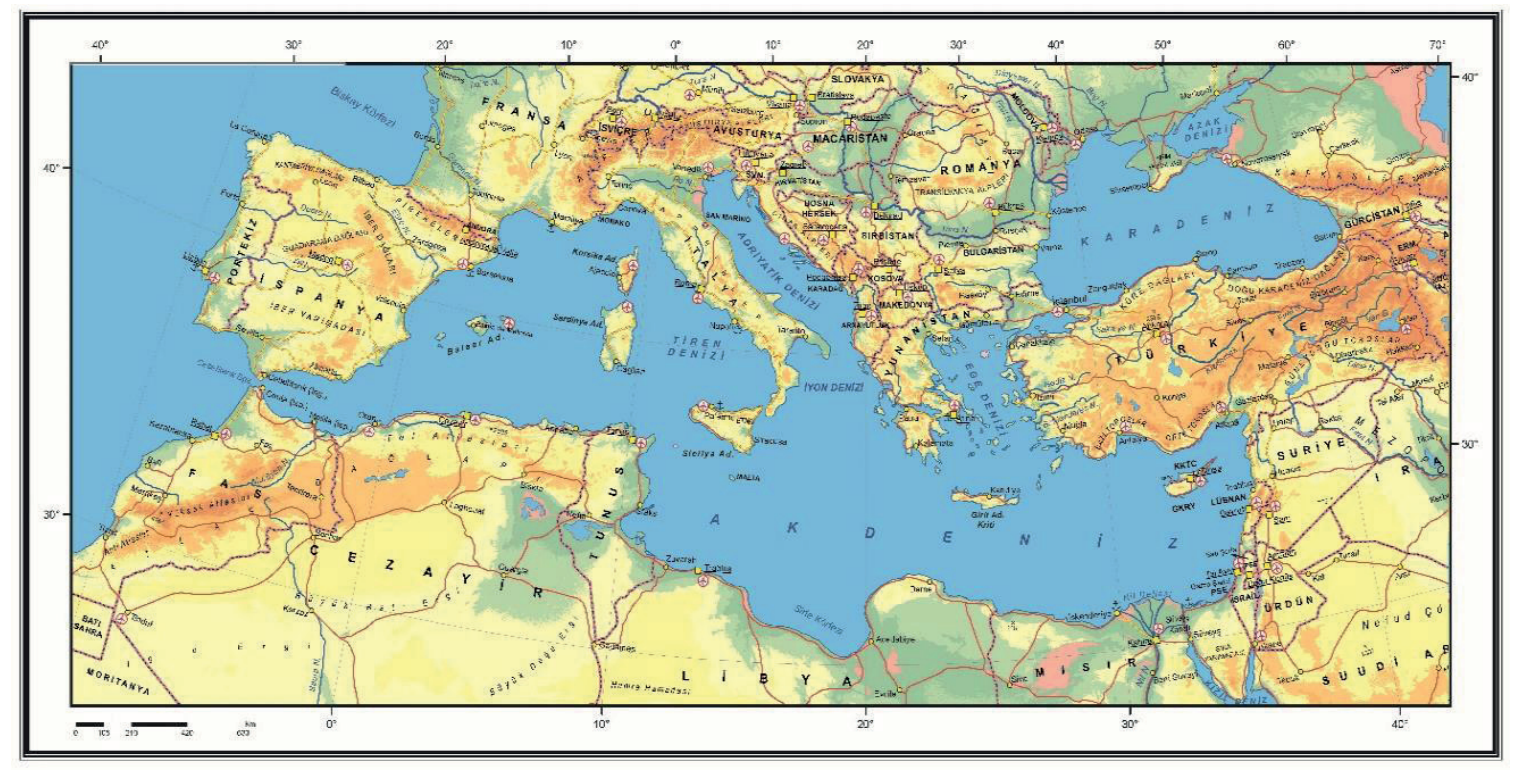

Şekil 1: Akdeniz Havzası'nın Coğrafi Konumu ve Kıyı Ülkeleri.

Figure 1: Location of the Mediterranean Basin and Coastal Countries.

Kaynak: Harita Genel Müdürlüğü (2020), Avrupa Fiziki Haritasından yararlanılmıştır. 
yaklaşımla arka planda nerede, neden, nasıl soruları sorularak işlenmiştir. Akdeniz ülkelerinde turizmin son durumu "Milenyum" başlığı altında analiz edilirken yapısal ve niceliksel durum sorgulanmış, ayrıca coğrafi dağılış da verilmiş̧tir. Çalışmada Akdeniz ülkelerinde turizmin geleceği konusu; uluslararası turist hareketleri ve küresel gelişmelerin bölgeye yansımaları bağlamında iki açıdan incelenmiştir.

\section{Tarihi ve Coğrafi Bakış Açısıyla Akdeniz Ülkelerinde Turizm}

\section{1. İlk Turizm Hareketleri}

Eski çağlarda insanların seyahat nedenleri ticaret, din, sağllk, kültür vb. amaçlı olmuştur. Birçok kaynağa göre seyahati ilk keşfedenler Sümerlerdir. Çünkü ticareti, yazıyı ve tekerleği bulan Sümerlerde ilk seyahatin de İ.Ö. 4000'lerde başladığ kabul görmektedir. Fenikeliler, modern anlamda bir yerden diğerine tüccar olarak giden ilk gerçek gezginlerdir. Eski Mısır, İ.Ö. 3000'lerde dünyanın çeşitli yerlerinden gelen insanlar tarafindan ziyaret edilen bir bölge olmuş, Mısır'a gelenler özellikle piramitleri ve tapınakları görmeyi amaçlamışlardır (Toskay, 1990). İ.Ö. 2000’li yıllarda Fenikelilerin bütün Akdeniz'e hâkim olacak şekilde deniz ticaretine başlamaları ve bu yolla Britanya Adaları, Batı Afrika ile Asor Adaları'na seyahat etmeleri de önemli bir gelişmedir (Sarı Çallı, 2015, s.9).

Eski Yunan'da İ.Ö. 776 yılında Olimpiyat Oyunları'nın başlaması ile spor karşılaşmalarına katılmak veya seyretmek üzere gelenler, bir anlamda spor turizminin öncüleri sayılmaktadır. Yunanlı tarihçi ve coğrafyacı Herodot, İ.Ö. 480421 yılları arasında ilk gezginlerden biridir ve kültür turizminin de uygulayıcısı olmuştur. Eski Yunanlılar, kaplıcalara, atletizm oyunlarına ve kâhinlerin bulundukları yerlere yoğun ilgi göstermişlerdir. Helenistik Dönem'de Efes'e ticaret, gezi ve eğlence amaçlı geliş-gidişler oldukça yoğunlaşmıştır (Toskay, 1990). Delphoi, kehanet tanrısı Apollon'a ev sahipliği yapması nedeniyle ünlenmiştir. Delphoi, antik dünyanın farklı kavim ve devletlerinden insanları bir araya toplayan bir destinasyon olarak değerlendirilmektedir (Tutan ve Başol, 2014). Ticaret, çağlar boyunca farklı seyahat yollarının oluşmasını sağlamıştır. Bu rotalar arasında en önemlisi İ.Ö. 600'lü yıllarda kullanılmaya başlanan ve Orta Asya'dan Avrupa içlerine kadar uzanan Ipek Yolu'dur (Sarı Çallı, 2015, s. 9).

Romalıların zevk için seyahat eden ilk turistler oldukları kabul edilmektedir. Romalı soylular ve zenginler, Anadolu'daki ve Yunanistan'daki tapınaklarda korunan heykelleri ve sanat eserlerini, Mısır'daki piramitleri ziyaret etmişlerdir. Deniz kıyısındaki dinlenme yerleri ve termal su mekânları lüks tatil destinasyonlarını oluşturmuştur. İlk zamanlar sadece tedavi için kullanılan şifalı su kaynaklarına sonradan kumar, eğlence ve keyif işlevleri de eklenmiştir. Bu çok yönlü hareketlilikte, merak ve zenginlik kadar, gemiler, karayolu ağ 1 ve konaklama hizmetinin gelişmiş olmasının da payı büyüktür. Roma İmparatorluğu'nun zayıflamaya başladığı dönemde, bozulan ekonomi, güvenlik sorunu ve hizmetlerin zayıflamasıyla turizm gerilemiştir (Toskay, 1990).

Orta Çağın ilk yarısında dini hareketler turizme damgasını vurmuştur. İnanç turizmi hem Avrupa'da hem de Ortadoğu'da kendini göstermiştir. Hristiyanlar Avrupa'da daha çok Tours (Fransa) kentini ve Roma'yı ziyaret etmişler, ayrıca İngiltere'de Canterbury'ye, Fransa'da Lourdes'a, Anadolu'da Efes'e ve kutsal topraklar olarak anılan Kudüs'e ziyaretler birer kutsal görev hâline gelmiştir (Özgüç, 2017). Kuzey Avrupa'dan Ortadoğu'ya gerçekleşen Haçlı Seferleri ise, dinsel amaçlı seyahatleri başlatması ve yaygınlaştırması açısından önemlidir.

\subsection{Rönesans'tan Ondokuzuncu Yüzyıla Turizm Hareketleri}

Ortaçağın teokratik, tutucu ve otoriter anlayışına bir tepki olarak ortaya çıkan Rönesans'la birlikte sanat gelişmiş, yeni opera, tiyatro binaları ve oteller yapılmış, insanlar eğlenceyi yeniden keşfetmişlerdir. Gezginler ticaret, eğlence ve keşif amaçlı seyahatler yapmışlardır. Özellikle İtalya'daki kültürel gelişme bu ülkeye yoğun bir ilginin doğmasına yol açmıştır. 16. yüzyıl, kıta aşırı deniz yolculuklarının yüzyılıdır, dolayısıyla Akdeniz dışarda kalmıştır. Ancak, bu denizin dışındaki gelişmelerden doğan sonuçlar (göç, zenginlik, kültür, mimari, politika vd.) Akdeniz'e taşınmıştır. 17. yüzyılın ikinci yarısından itibaren deniz suyuna ilgi artmaya ve deniz banyosunun faydaları öğrenilmeye başlamıştır (Toskay, 1990).

16.-18. yüzyıllar arasında prensler, soylular, devlet adamları, diplomatlar, sanatçılar, öğrenciler, bilim adamları ve zenginler tarafından gerçekleştirilen Büyük Tur/Grand Tour, modern turizmin erken formu ve öncüsü sayılmaktadır (Owen, 2019). Büyük Tur, yurtdışı gezilerine öncü olmuş, belirli güzergâhlar boyunca Batı ve Güney Avrupa dolaşılmıştır (Löschburg, 1998). Özellikle de Paris, Marsilya, Nice, Cenevre, Torino, Cenova, Roma, Napoli, Floransa ve Venedik başlıca varış noktalarını oluşturmuş, turlarda özel rehberler görev yapmışlardır (Kozak, vd. 2001). Ana hedefin geleceğin aristokratlarını ve liderlerini yetiştirmek olduğu bu uzun süreli turlar; yabancı dil bilgisi, gümrük, politika ve kültür-sanat bilgilerinin öğrenilmesini 
sağlamıştır (Zuelow, 2015). Rönesans dönemindeki seyahatler eğitim-kültür-sanat amaçlı olsa da içki, kumar ve eğlenceye de zaman ayrıldığı görülmektedir. Bu yolculuklar modern anlamda ilk otellerin açılmasını da teşvik etmiştir (Özgüç, 2017).

1789'daki Fransız Devrimi, Büyük Tur'un sonunu getirmiş, daha sonra demiryollarını yapımı, Avrupa'da turizm ve seyahatin yönünü tamamen değiştirmiştir (Rosenberg, 2017). Fransız Devrimi ile başlayan sosyal, siyasal ve ekonomik değişimler sonucunda ortaya çıkan burjuva sınıfı ve zenginler, uzak ülkelere gidip gezmek suretiyle turizm hareketini ciddi şekilde etkilemişlerdir (Yıldız, 2011). Avrupa ve Akdeniz'in batı yarısında bu gelişmeler yaşanırken Anadolu'da seyahat edenler için kervansaraylar inşa edilmiş ve çağdaş konaklama tesislerinin ilk örnekleri doğmuştur. 16. yüzyıl sonlarına doğru Osmanlı İmparatorluğu'nun Akdeniz'i de içine alan geniş topraklara sahip olmasıyla Akdeniz'in güvenliği için gerekli tedbirler alınmış, önemli ticaret güzergâhlarında yolculuklar yaşanmıştır. Evliya Çelebi'nin Seyahatnamesi, o dönemin toplumlarının kültürleri hakkında oldukça ayrıntılı bilgiler vermektedir (Kozak vd. 2001).

18. yüzyılda denize olan ilgi oldukça artmıştır. Hatta İngiltere'de, yoğun nüfuslu merkezlerde oturanlar kıyılara, kumsallara akın etmeye başlamışlardır. $\mathrm{Bu}$ devinimin hızla yayılması üzerine Dr. William Russel adlı bir hekim, 1730 y1lında ilk kez "Deniz Suyunun Şifalı Etkisi Üzerine Bir Araştırma" adlı kitabını yayımlamıştır. Böylece İngiltere güneyinde 1750'lerde başlayan denize girişler, Fransa'nın Manş Denizi kıyılarında görülmeye başlamış, 18. yüzyıl sonlarına doğru, sayfiye ve kaplıca kenti kavramı doğmuştur. Akdeniz kıyılarında Nice ve Côte d'Azur kıyıları öne çıkmıştır. Başlangıçta küçük bir balıkçı kasabası olan Nice, Akdeniz ikliminin çekici özellikleriyle giderek ünlenmiştir. Bu bölge önce İngilizlerin ilgisini çekmiş ve özellikle Kraliçe Victoria (1837-1901) döneminde, Büyük Britanya Adaları'ndan gelenlerin tatil beldesi hâline gelmiştir. Böylece Nice ve Côte d'Azur bir taraftan saray görünümündeki otellerle dolarken, öbür yandan eğlence yerleri ve gezinti yerleriyle lüks turizm merkezine dönüşmüştür (Eralp, 1983).

Modern turizmin erken veya ilk gelişim aşaması olarak adlandırılan süreç, 18. yüzyıldan 19. yüzyılın ilk çeyreğine kadar sürmüştür. Bu süreçte turistik seyahat, büyük ölçüde varlıklı azınlık bir nüfus ve eğitimli profesyonellerin gerçekleştirdiği bir etkinlik sayılmıştır. Toplumun oldukça küçük bir kesimi tarafından gerçekleştiren bu seyahatler, çoğunlukla Avrupa'nın önemli kültür başkentlerine ve eğitim merkezlerine uzun süreli ve yerel halktan izole bir şekilde yapılmıştır (Demir, 2017). 19. yüzyılın ilk çeyreğine gelindiğinde turizm, meslek sahibi orta sınıfın çocuklarına da hitap edici hâle gelmişti (Koshar, 2002). Sanayi Devrimi'nin beraberinde getirdiği yenilikler, modern turizm faaliyetlerinin ortaya çıkmasında, gelişmesinde, kitleselleşmesinde ve farklı alanlara yayılmasında büyük rol oynamıştır. İngiltere'de 1841 yılında kurulan ilk seyahat acentesi (Thomas Cook), bir kentten öbürüne gezi düzenleyerek ilk toplu seyahati gerçekleștirmiștir (Eralp, 1983). İlk paket turların organize edilmesi ve her şey dâhil olarak piyasaya sürülmesi, geniş halk kitleleri için deniz-kum-güneş ile karakterize olan Akdeniz Havzası'ndaki destinasyonlara olan ilgiyi artırmıştır.

19. yüzyılda Doğu Akdeniz'in romantizmi, bu kıyılardaki ülkelere büyük bir merak uyandırmıştır. Sarayların gizemleri, müzik, roman, resim gibi sanat dallarında üretilen eserler, seyahatler için özendirici olmuştur. Paris’ten başlayıp İstanbul'a, daha sonra Bağdat'a uzatılan Doğu Ekspresi, bat1-doğu arasında tren yolculuğunun önemli bir itici gücü olmuştur. Yine bu yüzyılda İtalya'da Ligurya Rivierası, Toskana bölgesi, Napoliten kıyıları, Sicilya ve Korsika'da kış aylarını geçirmek, Alplere gitmek, sağlık ve dinlenme açısından bir moda hâline gelmiştir. İngilizler kayak kulüpleri kurarak İsviçre ve Fransa Alplerine kaymaya gelmişlerdir (Chamailleurs, 2013). 19. yüzyılda bir diğer yenilik, gezi rehberi yayıncılığının gelişmesidir. Bu gezi rehberleri gezginlerin katkılarıyla oluşturulmuştur. Malta, İyonya Adaları, Yunanistan, Mora, Arnavutluk, Makedonya, İstanbul, Çanakkale ve Küçük Asya (Anadolu)'da şehirlerin geçmişi, tarihi yapıları ve doğal çekiciliklerinin yanı sıra ulaşım araçları, tarifeler, yeme-içme olanakları, rotalar, oteller ve toplumun örf ve adetleri gibi her türlü bilgi okuyucuya sunulmuştur. Bütün bu bilgiler, insanlarda merak uyandırarak turizme katılmayı teşvik etmiştir (Arslan, 2014).

\subsection{Yirminci Yüzyılda Turizm Hareketleri}

Turizmin tarihsel gelişiminde 19. yüzyılın ilk çeyreğinden 20. yüzyılın ortalarına kadar geçen süre, "modern turizme giriș evresi" olarak adlandırılmaktadır. Bu dönem, orta sınıf seyahat kültürünün oluşumu, popüler destinasyonların ortaya çıkması bakımından kapsayıcı gelişmelere tanıklık etmiştir: sanayileşme, kentleşme, demografik değişkenler ve ulaşımdaki gelişmeler, sosyal hayat, işçi hakları, gelir artışları ve talepteki değişmeler vb. Ancak, 1929 Dünya Ekonomik Krizi ve ardından II. Dünya Savaşı turizmdeki gelişmeyi engellemiş, ulusal ve uluslararası turizm hareketleri oldukça daralmıştır. Yirminci yüzyılda önceki döneme göre oldukça modernleşen turizm olgusu, kitle turizmine dönüşümü hazırlamıştır (Gyr, 2010). Turizm, 20. yüzyılın ikinci 
yarısından itibaren tüm dünya ülkelerinin dikkatlerini çeken bir sektör olarak yerini sağlamlaştırmış, turizmde öncü ülkelere yenileri eklenmiş, az gelişmiş ülkeler kalkınma için turizmden yararlanmaya başlamışlardır.

Akdeniz dünyasında turizm, her ne kadar Avrupalı soyluların 17. yüzyılda başlayan kültür, sanat, eğitim amaçlı seyahatleri ile görülmeye başlasa da turizmin kitlesel hâle gelmesi II. Dünya Savaşı sonrasında gerçekleşmiştir. Nitekim 1940'ların sonunda, Fransa'nın güneydoğusu ile İtalya'nın kuzeyi kitlesel ziyaretlere açılırken, Akdeniz'in diğer yerleri henüz kitle turizmi ile tanışmamıştır (Magnan, 2009). Gerçek anlamda kitle turizmi 1960'lı yılların sonrasında başlamış, turizm orta sınıf arasında hızla yayılarak (seyahatin demokratikleşmesi) deniz-kum-güneş ve eğlence motivasyonlu kısa süreli ziyaretler önem kazanmıştır (Urry, 2009). Avrupa'da turizm, yeni mekânlara yönelerek özellikle Akdeniz ülkeleri, önemli bir pazar hâline gelmiştir. Başlangıçta Fransa, İspanya ve İtalya kıyılarına, ardından Yunanistan, Malta, Kıbrıs Adası ve Türkiye kıyılarına kitlesel turist akışı gerçekleşmiştir. Akdeniz kıyılarına doğru kitleler hâlinde gerçekleşen bu hareketlilik, büyük oranda mevsimsel karakter taşısa da iklim koşullarının uygunluğu sayesinde bazı destinasyonlarda (sözgelimi İspanya'nın Costa del Sol bölgesi) yaz ayları dışına da uzayabilmektedir. Turizme ilişkin altyapı ve üstyapı tesislerinin kıyılarda kümelenmesi, kitle turizminde mekânsal yoğunlaşmaya yol açmıştır (Bramwell, 2004).

$\mathrm{Bu}$ yüzyılda denize girmenin sağlıklı olduğu düşüncesinin hızla yayılmas1, Urry'nin (2009, s.39) deyimiyle "deniz banyosu" yapanların sayısında önemli bir artışa neden olmuştur. Akdeniz turizminde kıyıların ve denizin öne çıkmasında baskın rolü olan iklim koşullarında, kimi zaman güneş, denizin önüne geçmiştir. $\mathrm{Bu}$ süreç ile ilgili olarak Urry (2009, s.70) şu bilgileri aktarmaktadır: "Savaşs sonrası dönemde çekicilik kaynağı deniz değil aslında güneştir. İdeal beden bronzlaşmış beden olarak toplumun tüm sinıflarına nüfuz etmiştir. Kuzey Avrupa'daki klyılar güneşi ve bronzlaşmayı garanti edemediklerinden Akdeniz klyısındaki tatil yerleri muazzam ölçüde gelişmiştir. Bu gelişme Fransa ve İspanya ile başlamış, Yunanistan, İtalya ve daha sonra da Türkiye ve Kuzey Afrika'ya yayılmıştır".

Dünyada kitle turizminin yaygınlaşması, kıyıların turistikleşmesine, turistik mal ve hizmetlere olan talebin artmasına yol açmıştır. $\mathrm{Bu}$ süreçte turizme dayalı kentleşme -turistik kentleşme- olgusu ortaya çıkmıştır. Mullins (1991) turizm kentlerini, "çok sayıda turisti başta eğlence, dinlenme ve doyum sağlamak üzere çok çeşitli tüketime yönlendiren, hizmetlerin büyük bir kısmının kısa bir zamanda tüketilmesinin hedeflendiği kentler" olarak tanımlamaktadır. Turistikleşmiş kentler, yoğun bir yerli-yabancı nüfus artışıyla karşılaşmakta, çalışan nüfusun büyük bölümü turizmde istihdam edilmekte, oteller, yat limanları, turistik hizmet alanları ve ikinci konutlarla diğer kentlerden farklı kentsel kültürel peyzajlara sahip olmaktadır. Turizmde kentleşmenin Türkiye'deki en dikkate değer örneklerinden biri olan Antalya, Işık ve Zoğal (2017) tarafindan incelenmiştir.

II. Dünya Savaşı sonrasından Milenyum'a kadar olan dönem, birçok alt dönemlere ayrılmaktadır. Sözgelimi Manera ve Morey (2016, s. 87), Akdeniz bölgesinde turizmin seyrini beş aşamaya ayırmıştır: 1949-1972 arasında yayllımcı aşama; 1973-1978 arasında birçok ülkede ekonomik kriz ve siyasi istikrarsızlık nedeniyle açık bir daralma aşamast; 1979-1990 arasında yeni atılımlar aşaması, İran-Irak savaşı ve ikinci petrol krizinin sonuçlarıyla sarsılan 1991-1993 arasındaki kısa süreli daralma aşaması ve son olarak, 1994'te başlayan yeni dönem. Bu görüşü doğrulayan en tipik örnek; 1950-1970 arasında, günümüzde Dünya'nın en önemli turizm destinasyonlarından biri olan İspanya'nın Akdeniz kıyılarında Avrupa'daki Fordist-Keynesyen rejiminin de etkisiyle büyük bir turizm ve emlak patlaması yaşaması ve bunun sonucunda ülke genelinde binlerce turistik mekân (kent) ortaya çıkmasıdır. Rovira-Soto ve Clave (2017; 2018); kıyıların turizme dayalı coğrafi görünüm kazanmasında devletin destekleyici kararlarının ve mekânsal planlamanın önemini belirterek, İspanya'nın Costa Daurada kıyılarının turistik mekânsal kimliğe sahip olduğunu ortaya koymuştur.

20. yüzyılın son çeyreğinde, Avrupa'daki uluslararası turizm hareketlerinin ve turistik gelirin 1/3'ünü Akdeniz ülkeleri sağlamış, 1980'lerin ikinci yarısında yatak kapasitesi 5 milyona ulaşmıştır (Baykal, 1992, s.34-35). Akdeniz imajının en büyük çekiciliklerinden biri olan nitelikli konaklama arzının (LozatoGiotart, 1990, s.83) ilk lüks tesisleri kuzeybatı Akdeniz'de hizmete girmiş, aynı zamanda burası en fazla paya sahip olmuştur: 1970 'de $\% 81,4,1986$ 'da $\% 84,6$ ve 2018 'de $\% 70$. Bu oransal azalma en başta Türkiye olmak üzere başka ülkelerin konaklama kapasitelerinin artışıla ilgilidir.

Kitle turizminin son kırk-elli yılda inanılmaz yükselişi, beraberinde birtakım olumsuz sorunlar yaratmıştır. Nitekim 1980'lerde Akdeniz ülkelerinde turizmin de dâhil olduğu her yöndeki, her türdeki hareketlilik, aşırı-yanlış kullanımlar, çeşitli bitki ve hayvan türlerinde radikal bir azalmaya yol açmıştır (Selwyn, 2000, s.242). Diğer yandan dünyada çevresel duyarlılıkların artması, sürdürülebilir turizm, alternatif turizm, sorumlu turizm gibi yaklaşımları gündeme getirmiş, pek çok 
ülkede yaptırımlar ve uygulamalar devreye sokulmuştur. Turizmin kitleselleşmesi sonucunda alternatif arayışlar ve sürdürülebilirlik çerçevesinde postmodern turizm paradigması ortaya çıkmış, gerçeküstü ve sanal deneyimler, bilgi ve iletişim teknolojilerindeki yenilikler, aşırı derecede bireyselleşmiş bir turizm endüstrisi yaratmıştır (Akoğlan Kozak, Evren ve Çakır, 2013, s.17).

20. yüzyılın sonuna gelindiğinde turizm, dünyanın her köşesinde farklı türlerde, yılın on iki ayında uygulanır boyuta ulaşmıştır. Aynı şekilde tatillerde turist hareketliliği patlama derecesinde iç ve dış turizm sarmalında, yılda bir kez yerine ikiye, üçe katlanır olmuştur. Turizmin bu inanılmaz büyümesi ve çok sayıdaki sektörle bağlantılarının olması, örgütlenme, strateji, plan, tanıtım, pazarlama ve rekabet gibi konuları, hatta siyasi ilişkileri bile turizmin merkezine ve gündemine oturtmuştur. Turizmin çok boyutlu ilişkiler bütünü olması, ona birçok kolaylıklar getirdiği gibi, onu daha kırılgan, çabuk etkilenen bir yapıya sokmuştur. $\mathrm{Bu}$ da turizmi tehdit eden unsurların çok sayıda olduğunu hatırlatarak risk yönetimini daha da vazgeçilmez yapmıştır.

Son elli y1lda turizmin önünü açan, çeşitlenmesini sağlayan, yönünü belirleyen olumlu gelişmeler dışında turizmin yavaşladığı, kesintiye uğradığı yıllar da vardır ki bunlar, Akdeniz Havzası'ndaki turist hareketliliğini derinden etkilemiştir. Sözgelimi 1974 dünya petrol krizi, Lübnan'da iç savaş (1975-1990), İtalya'da kolera salgını (1966), Kıbrıs Adası yönetiminin ikiye bölünmesi (1974), Yunanistan'da darbe ve cunta yönetimi (1967-1974), Körfez Savaşı (1990-1991) ve Yugoslavya'daki iç karışıklıklar, savaşla birlikte dağılma süreci ve yeni bağımsız devletler (1980'lerden 2008'e), Akdeniz ülkelerindeki terör eylemleri vd. (Baykal, 1992, s. 30, Encyclopædia Britannica, 2019).

\section{Milenyum'da Akdeniz Ülkelerinde Turizm ve Coğrafi Dağılış}

Terkenli, Bellas ve Jenkins (2007, s.38-39), 2000'li yılların başında, rekreasyon ve turizmin Akdeniz ülkelerinde de görüldüğü üzere peyzajları aslından uzaklaştırarak bir dönüşüme yol açtığına, yer kimliğinin sürekli etkilenmeyle yeniden üretildiğine ve bu bağlamda coğrafi farklılıkların ortaya çıktığına dikkatleri çekmiştir. Böylece Milenyum'a gelindiğinde Akdeniz ülkelerinde turizm, gelişmişlik açısından üçlü bir ayrıma sahne olmuştur: (i) ilk öncü ülkeler: İspanya, Fransa ve İtalya, (ii) turizm sürecine daha sonra katılanlar: Yunanistan, Mısır, Türkiye, Tunus, Fas, (iii) turizm değişkenlerine göre Akdeniz ortalamasının altında kalanlar: Arnavutluk, Cezayir, İsrail,
Libya, Malta ve Monako (Manera ve Morey, 2016, s.88). İște bu ülkelerde turizmin etkileri de farklı boyutlarda ve değişik zeminlerde karşımıza çıkmaktadır.

\subsection{Yapısal Özellikler}

Akdeniz çevresinin doğal ve kültürel miras bütünselliği, "Akdeniz Havzası'nın gerçek zenginliği” olarak ifade edilmektedir. Ne var ki son elli yılda teknolojik, ekonomik, demografik ve sosyal değişimler, kıyılarda yer yer tehdit edici boyutlara ulaşmıştır. Sözgelimi Akdeniz kıyıları boyunca turizmin uzun yıllardır yayılması, kıyı ardülkesindeki tarımsal ekonomilerin bozulmalarına yol açmıştır. Tarihsel Akdeniz'in polikültür tarımı, yerini büyük ölçüde turizme bırakmıştır. $\mathrm{Bu}$ dönüşüm, kıyılar tarafından iç alanların doğal ve kültürel kaynaklarının eritilmesi ve marjinalleşmesi anlamına gelmektedir. Akdeniz turizminin günümüzdeki yapısal özellikleri şu şekilde yorumlanabilir:

1. Akdeniz Havzası'nın dört temel turistik çekiciliği vardır: (i) tarihi, kültürel, doğal miras unsurları, (ii) ayrıcalıklı iklim, deniz ve özel kıyılar, (iii) Avrupa pazarının Akdeniz'e kültürel ve fiziksel yakınlığı, (iv) eski bir turizm geçmişi (PNUE/PAM, 2005, s.2-3).

2. "Akdenizli" kimliği kültürel yayılma sonucunda ortak özelliklere sahip olduğu gibi (mimari, mutfak, sanat, yaşam tarzı vb.) ayrışmalar da görülmektedir (doğu-batı ve kuzeygüney eksenindeki kültürel çeşitlilik gibi).

3. Akdeniz'de en gelişmiş turizm türlerinden ilk üçünü, turistik arz potansiyeline bağlı olarak ve küresel dinamiklerin de etkisiyle kıyı turizmi, kültür turizmi ve kruvaziyer turizmi oluşturmaktadır. Dünya'da kruvaziyer turizminin büyük bir atılım içine girmesi (Atout France, 2016), Özellikle Ege Denizi, Adriyatik Denizi, Batı Akdeniz ve turistik adaların yoğun talep görmesine yol açmıştır. Ayrıca ekoturizm de Akdeniz'in küresel biyoçeșitliliğgin sıcak noktalarından biri olması nedeniyle sayısız firsatlara sahiptir. (Plan Bleu, 2016).

4. Akdeniz ülkelerine gelen turistlerin büyük kısmı Avrupa Kıtası'ndandır (yaklaşık \% 80). Ayrıca Amerika kıtası ve Uzakdoğu'dan da yüksek talepler vardır ve bu kıta dışı gelenlerin Akdeniz'de yoğunlaştığı ülkelerin başında Yunanistan, İsrail ve İtalya gelmektedir. Akdeniz ülkelerinin turist hareketliliğinde en fazla otomobil kullanılmaktadır. Konaklamalarda ise ikinci konutlar ve kiralık evler daha çok tercih edilmektedir (PNUE/PAM, 2005, s.5-6). 
5. Akdeniz kıyılarında geçmişten bugüne yeni destinasyonların gelişiminde, turistik hareketin yönünde ve izlenen rotalarda, ayrıca turizmin promosyonu ve pazarlanmasında en büyük etki tur operatörlerine aittir. Bölgenin geleneksel ülkeleri olan Fransa, İspanya ve İtalya üçlüsü dışında, yıldan yıla farklı ülkelerin (sözgelimi: Yunanistan, Hırvatistan, Türkiye, Tunus, Misır vd.) turizmde yıldızının parlamasında, birinin yerine diğerinin geçmesinde, tur operatörleri büyük rol oynamaktadır.

6. Akdeniz'de turizm; balıkçılık, tarım, ulaşım, inşaat, ticaret, sanayi vd. sektörler ile aynı kıyıları paylaşmaktadır. Sektörler arasında simbiyotik (karşılıklı yarar) ilişki ve holistik (bütüncül) bir yapılanma görülse de aralarında rekabet yaşanmakta, hatta birinden diğerine olumsuz etkiler ortaya çıkmaktadır. Sonuç olarak kıyılarda ve deniz suyunda kirlilik, aslından uzaklaşmış peyzajlar giderek çoğalmaktadır. Şu da bir gerçektir ki, dünya deniz trafiğinin \%30'u Akdeniz'de gerçekleşiyorsa ve her 3 Akdenizli'den 2'si kentsel alanlarda yaşıyorsa ve Akdeniz kıyılarının \%40’1 yapay hâle gelmişse (Plan Bleu, 2016), bundan tek sorumlu olarak turizmi tutmak mümkün değildir.

7. Ekonomi, dış politika, uluslararası göç, güvenlik ve çevre ile ilgili sorunlar, Akdeniz ülkelerini de tehdit etmektedir. Bu iç içe geçmiş sorunlar, Akdeniz'in kültürel kimliğini, belleklere yerleşmiş geleneksel doğal ve kültürel peyzajlarını ve de bölgenin itibarını zedeleyecek duruma geldiği takdirde, turistlerin Akdeniz'den uzaklaşma olasılığı gündeme gelebilecektir.

İçinde bulunduğumuz yüzyılın ilk çeyreğinde, bilgi ve iletişim alanında yaşanan gelişmeler, turizm tarihinde yeni bir kırılma noktasına yol açarak postmodern turizm dönemine geçişi hızlandırmıştır. Bu yeni dönemin temeli, internet teknolojisi ile atılmıştır. Özellikle 1990'lı yılların başından itibaren internet, küresel ölçekte hızla yaygınlaşmış ve gündelik hayatın ayrılmaz bir parçası konumuna yükselmiştir. Diğer taraftan, 2000'li yılların başlarından itibaren sosyal medya platformlarındaki artış, ilgi alanları benzer bireyleri zamandan ve mekândan bağımsız olarak bir araya getirmiştir.

Günümüzde ağ toplumu ve paylaşım kültürünün gelişimiyle, geçmişte sadece geleneksel merkezlerden beslenen kullanıcıların hâkimiyet alanı giderek genişlemektedir. İnsanlar arasında gerçekleşen paylaşımlar ve değiş-tokuşlar; ulaşım (araç ve yolculuk paylaşımları), konaklama (konut ve oda paylaşımı ve konut değiş-tokuşu), yiyecek-içecek ve aktivite paylaşımları, turizm coğrafyasının da ilgi alanlarını içerik bakımından değiştirmiştir. Bütün bu devrimsel nitelikteki teknolojik ve sosyo-kültürel temelli yenilikler, Akdeniz kıyı ülkelerine de hızla yayılmış ve mevcut yapısal düzen, yeni sosyo-mekânsal evrilmelerin yaşandığı bir sürece girmiştir.

\subsection{Niceliksel Özellikler ve Coğrafi Dağılıș}

Avrupa bir kıta destinasyon olarak, uluslararası turist sayıs1 ve turizm gelirinde geçmişten bugüne dünyanın lideri konumundadır. Dünya Turizm Örgütü’ne (UNWTO, 2019) göre 2018 y1lında 1 milyar 401 milyona ulaşan uluslararası turist hacminin 710 milyonu (\%50,7) Avrupa Kitası'na aittir. Yakın geçmişten (1970) itibaren Avrupa ve Akdeniz ülkelerinin uluslararası turist sayısı ve oransal değerleri oldukça değişmiştir (Tablo 1). Nitekim, 1970 yılında uluslararas1 turist hareketlerinden Avrupa'nın aldı̆̆ 1 pay \%68'den 2018 yılında \%50’ye gerilemiş, aynı yıllar karşılaştırmasına göre Akdeniz ülkelerinin payı da \%35'den \%28'e düşmüştür.

Sözgelimi İspanya, Fransa ve İtalya 1970 yllında Akdeniz'deki uluslararas1 turistlerin \%82'sini, 1980'de \%79'unu, 2000'de \%75'ini (PNUE/PAM, 2005, s.9) ve 2018'de \%60'ını (Tablo 4) alarak, havzadaki ağırlığını devam ettirmiştir. Ancak kuzeybatı Akdeniz'in son elli yılda Akdeniz Havzası turizminden aldığ1 payın \%82'den \%60'a düşmesinin birçok

Tablo 1: Uluslararası Turist Sayısının Dünya, Avrupa ve Akdeniz Ülkelerinde Yıllara Göre Değişimi.

Table 1: Change in the Number of International Tourists in the World, Europe and Mediterranean Countries by Years.

\begin{tabular}{|c|c|c|c|c|c|}
\hline Yıllar & Dünya & Avrupa & $\begin{array}{c}\text { Avrupa'nın Dünyadaki } \\
\text { Payı (\%) }\end{array}$ & Akdeniz Ülkeleri & $\begin{array}{l}\text { Akdeniz Ülkelerinin } \\
\text { Dünyadaki Payı (\%) }\end{array}$ \\
\hline 1970 & 165.787 & 113.000 & 68 & 58.085 & 35 \\
\hline 1980 & 285.997 & 188.072 & 66 & 95.815 & 34 \\
\hline 1990 & 455.900 & 280.600 & 62 & 153.374 & 34 \\
\hline 2000 & 687.300 & 392.700 & 57 & 220.875 & 32 \\
\hline 2010 & 952.000 & 487.000 & 51 & 296.702 & 31 \\
\hline 2018 & 1.401 .000 & 710.000 & 50 & 389.470 & $28^{*}$ \\
\hline
\end{tabular}

Kaynak: PNUE/PAM, 2005; UNWTO, 2019

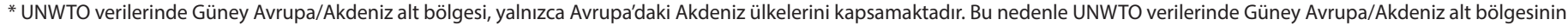

dünyadaki payı \%21 iken, Akdeniz'e kıyısı olan diğer ülkelerin verileri de eklendiğinde bu oran \%28'e yükselmektedir. 
nedeni olmakla beraber özellikle kuzeydoğu Akdeniz’in (Adriyatik ülkeleri, Yunanistan ve Türkiye) turizmde atılım göstermesi önemli bir etken olmuştur. Nitekim bu ülkelerin 2000'deki toplam payı \%13'den 2018'de \%27'ye yükselmiştir (Bozok ve Köroğlu, 2007, s.147-149). Bu durumda günümüzdeki asıl eşitsizlik, Akdeniz'in kuzey kıyı ülkeleri (Avrupa) ile güney kıyı ülkeleri (Afrika) arasındadır: \%87'e karşılık \%13 (Tablo 4).

Avrupa'nın 2018 yılı itibariyle uluslararası turist sayısı ve turizm gelirinin kıta içi bölgesel dağılımı ve Dünya'dan aldığ1 pay, Dünya Turizm Örgütü'nün bölgeleme sistemine göre aşağıdaki sonuçları ortaya koymaktadır. Görüldüğü üzere Güney Avrupa/Akdeniz Bölgesi 289 milyon turist (\%20) ile kitada ilk sıradadır (UNWTO, 2019). Aynı şekilde 2018 yılı itibariyle, 1 milyar 451 milyon \$ olan uluslararası turizm gelirinden Avrupa \%39,3'lük pay almış onun da \%15,2'ini Güney Avrupa/Akdeniz Bölgesi karşılamıştır (Tablo 2).
Uluslararası turist sayısının 2018 yılı itibariyle ülkelere dağılımında; ilk 10'un içinde Avrupa'dan 5 ülke yer almaktadır ve bu ülkelerden 4'ü (Fransa, İspanya, İtalya ve Türkiye) Akdeniz'e kıyısı olan ülkelerdir. Fransa, uluslararası turistlerin \%6,4'üne, İspanya \%5,9'una, İtalya \%4,4'üne, Türkiye ise \%3,3'üne sahiptir. Uluslararası turizm gelirinde ise ilk 10'da Avrupa'dan yine 5 ülke yer alırken bunlardan 3'ü (İspanya, Fransa ve İtalya) Akdeniz ülkeleridir (Tablo 3).

Akdeniz'de uluslararası turizm hareketlerinde ilk 10'a giremeyen diğer ülkeler arasında, Yunanistan, Hırvatistan, Fas ve Mısır başta gelmektedir. Libya ve Suriye’ye ilişkin güncel veriler bulunmamaktadır (Tablo 4).

Avrupa Birliği İstatistik Ofisi'nin (Eurostat, 2020) yayımladığı verilere göre, 2018 yılı itibariyle Avrupa'da en fazla yatak kapasitesine sahip ülkeler siralamasında ilk 3 sirayı

Tablo 2: Uluslararası Turist Sayısı ve Turizm Gelirinin Bölgesel Dağılımı (2018). Table 2: Regional Distribution of International Tourist Numbers and Tourism Income (2018).

\begin{tabular}{|c|c|c|c|c|}
\hline \multirow{2}{*}{ Bölgeler } & \multicolumn{2}{|c|}{ Uluslararası Turist Sayısı* } & \multicolumn{2}{|c|}{ Uluslararası Turizm Geliri* } \\
\hline & Milyon & $\%$ & Milyar \$ & $\%$ \\
\hline Avrupa & 710 & 50,7 & 570.5 & 39,3 \\
\hline Kuzey Avrupa & 78.9 & 5,6 & 93.9 & 6,5 \\
\hline Batı Avrupa & 200.4 & 14,3 & 187.5 & 12,9 \\
\hline Orta ve Doğu Avrupa & 141.4 & 10,1 & 68.7 & 4,7 \\
\hline Güney Avrupa/Akdeniz & 289.4 & 20,7 & 220.4 & 15,2 \\
\hline Asya-Pasifik & 347.7 & 24,8 & 435.5 & 30 \\
\hline Amerika & 215.7 & 15,4 & 333.6 & 23 \\
\hline Afrika & 67.1 & 4,8 & 38.4 & 2,6 \\
\hline Orta Doğu & 60.5 & 4,3 & 73.0 & 5 \\
\hline Dünya & 1.401 & 100 & 1.451 & 100 \\
\hline
\end{tabular}

Kaynak: UNWTO, 2017; 2019

*Turist sayısı, turizm geliri ve yüzdeler yuvarlanmıştır.

Tablo 3: Uluslararası Turist Sayısı ve Turizm Gelirine Göre İlk 10 Ülke (2018).

Table 3: Top 10 Countries by International Tourist Numbers and Tourism Income (2018).

\begin{tabular}{|c|c|c|c|c|c|}
\hline \multirow{2}{*}{ Ülkeler } & \multicolumn{2}{|c|}{$\begin{array}{c}\text { Uluslararası Turist } \\
\text { Sayısı * }\end{array}$} & \multirow[t]{2}{*}{ Ülkeler } & \multicolumn{2}{|c|}{$\begin{array}{c}\text { Uluslararası } \\
\text { Turizm Geliri * }\end{array}$} \\
\hline & Milyon & $\%$ & & Milyar \$ & $\%$ \\
\hline Fransa & 89 & 6,4 & $A B D$ & 214 & 14,8 \\
\hline İspanya & 83 & 5,9 & İspanya & 74 & 5,1 \\
\hline$A B D$ & 80 & 5,7 & Fransa & 67 & 4,6 \\
\hline Çin & 63 & 4,5 & Tayland & 63 & 4,3 \\
\hline İtalya & 62 & 4,4 & Birleşik Krallık & 52 & 3,6 \\
\hline Türkiye & 46 & 3,3 & İtalya & 49 & 3,4 \\
\hline Meksika & 41 & 2,9 & Avustralya & 45 & 3,1 \\
\hline Almanya & 39 & 2,8 & Almanya & 43 & 3,0 \\
\hline Tayland & 38 & 2,7 & Japonya & 41 & 2,8 \\
\hline Birleşik Krallık & 36 & 2,6 & Çin & 40 & 2,8 \\
\hline İlk 10 Ülke & 577 & 41,2 & İlk 10 Ülke & 688 & 47,4 \\
\hline Dünya & 1.400 & 100 & Dünya & 1.451 & 100 \\
\hline
\end{tabular}

Kaynak: UNWTO, 2019

*Turist sayısı, turizm geliri ve yüzdeler yuvarlanmıştır. 
Tablo 4: Akdeniz Ülkelerinin Uluslararası Turist Sayısı ve Turizm Geliri (2018).

Table 4: International Tourist Numbers and Tourism Income in Mediterranean Countries (2018).

\begin{tabular}{|c|c|c|c|c|c|}
\hline & \multirow{2}{*}{ Ülkeler } & \multicolumn{2}{|c|}{ Uluslararası Turist Sayısı * } & \multicolumn{2}{|c|}{ Uluslararası Turizm Geliri * } \\
\hline & & Milyon & $\%$ & Milyon \$ & $\%$ \\
\hline 1 & Fransa & 89.400 & 22,95 & 67.370 & 22,66 \\
\hline 2 & İspanya & 82.773 & 21,25 & 73.765 & 24,81 \\
\hline 3 & İtalya & 62.146 & 15,96 & 49.262 & 16,57 \\
\hline 4 & Türkiye & 45.768 & 11,75 & 25.220 & 8,48 \\
\hline 5 & Yunanistan & 30.123 & 7,73 & 19.029 & 6,40 \\
\hline 6 & Hırvatistan & 16.645 & 4,27 & 11.831 & 3,98 \\
\hline 7 & Fas & 12.289 & 3,16 & 7.775 & 2,62 \\
\hline 8 & Mısır & 11.346 & 2,91 & 11.615 & 3,91 \\
\hline 9 & Tunus & 8.299 & 2,13 & 1.713 & 0,58 \\
\hline 10 & Kıbrıs** & 5.698 & 1,46 & 4.312 & 1,45 \\
\hline & KKTC & (1.759) & - & (960) & - \\
\hline & GKRY & (3.939) & - & (3.352) & - \\
\hline 11 & Arnavutluk & 5.340 & 1,37 & 2.193 & 0,74 \\
\hline 12 & Slovenya & 4.425 & 1,14 & 3.194 & 1,07 \\
\hline 13 & İsrail & 4.121 & 1,06 & 7.241 & 2,44 \\
\hline 14 & Malta & 2.599 & 0,67 & 1.854 & 0,62 \\
\hline 15 & Cezayir ${ }^{* * *}$ & 2.451 & 0,63 & 0,141 & 0,05 \\
\hline 16 & Karadağ & 2.077 & 0,53 & 1.199 & 0,40 \\
\hline 17 & Lübnan & 1.964 & 0,51 & 8.400 & 2,83 \\
\hline 18 & Bosna-Hersek & 1.053 & 0,27 & .939 & 0,32 \\
\hline 19 & Filistin & .606 & 0,16 & .245 & 0,08 \\
\hline 20 & Monako & .347 & 0,09 & - & - \\
\hline 21 & Libya $^{* * * *}$ & - & - & - & - \\
\hline \multirow[t]{4}{*}{22} & Suriye $e^{* * * *}$ & - & - & - & - \\
\hline & Akdeniz Havzası & 389.470 & 28 & 297.298 & 20 \\
\hline & Avrupa & 710.000 & 50 & 483.000 & 33 \\
\hline & Dünya & 1.400 .000 & 100 & 1.451 .000 & 100 \\
\hline
\end{tabular}

Kaynak: UNWTO, 2019; KKTC Turizm Planlama Dairesi, 2018

*Turist sayısı, turizm geliri ve yüzdeler yuvarlanmıştır.

**UNWTO'da eksik olan istatistikler KKTC Turizm Planlama Dairesi'nden tamamlanmıştır.

${ }^{* * *}$ Cezayir'e ait veriler 2017 yılına aittir.

****Libya ve Suriye'ye ait güncel verilere ulaşılamamıştır.

Akdeniz'den İtalya, Fransa ve İspanya almaktadır. Rapor, son yıllarda oldukça popüler hâle gelen kiralık evler ve kamp tesislerine ilişkin verileri de kapsamaktadır. Rapordaki temel eksiklik, $\mathrm{AB}$ dışındaki Akdeniz ülkelerine ilişkin verilerin olmamasıdır. Bu eksiklik ülkelerin yayınladıkları resmi turizm istatistikleri ve diğer kaynaklar ile tamamlanmaya çalışılmıştır. Verilere göre İtalya, kampingler hariç diğer tüm tesis türü ve yatak kapasitesinde ilk sıradadır. Kampinglerde ise Fransa birinci sıradadır. Toplam yatak sayısında İtalya'yı Fransa, İspanya, Türkiye ve Yunanistan izlemektedir (Tablo 5). Kisa süreli kiralık evlere ülkelerin tutumları farklı olduğundan verilerin doğruluğu şüphelidir. Sözgelimi Türkiye'de kısa süreli kiralık evlere iliş̧in resmi bir kaynak yoktur. Bu nedenle ülkeler arası karşılaştırmaları otel ve benzeri tesisleri dikkate alarak yapmak daha sağlıklı olmaktadır.

\section{Akdeniz Ülkelerinde Turizmin Geleceğine Bakış}

Turizm sektörü bugün her zamankinden daha fazla yeni nesil dijital girişimciler tarafından derinden değiştirilmiş, son derece teknolojik bir endüstri hâline gelmiştir. Bu nedenle, bir taraftan geleneksel aktörlerin yeniliklere uyumunu, diğer taraftan yaratıcılıklarının sınırı henüz belli olmayan yeni aktörlerle turizmin nasıl şekilleneceğini tahmin etmek oldukça zordur. Acaba 2050'de Y kuşağının torunları ve Z kuşağının çocukları hangi buluşları yapacaklar, hangi tür turizmi tüketmek isteyecekler ve nerelere gitmeyi tercih edeceklerdir? Bütün bu sorulara yanıt bulmak ve turizmin geleceğini tartışmak üzere 2016 yılında Fransa'da "Turizmde Yenilik ve Girişimcilik" adlı toplantıda birçok konu masaya yatırılmıştır (DGE, 2016). Konuların 12 başlıkta gruplandırıldığı toplantıda 2050 turizmi için başlıca şu görüşler öne çıkmıştır: konaklama sektörü esnek hâle gelecek ve sınırsız bir arza sahip olacak, işbirlikçi konaklama daha da yaygınlaşacak; yeni pazarlar gelişecek; turistler gitgide daha fazla bilinçli olacak, turist her türlü işlemden kurtularak kapıdan kapıya kent turizmine katılacak, turist hareketliliği iki kat, arz ise üç kat artış gösterecek, hem adrenalin ve heyecan talebi artacak hem de tam tersi olarak "yavaş turizm" konseptinde rahatlama, detoks, bağlantısız, doğa, sağlik ve nihayetinde özgünlük talebine yanıt vermek gerekecek; eğlence parklarına 
Tablo 5: Akdeniz Ülkelerinde Konaklama Tesis Türüne Göre Tesis ve Yatak Sayısı (2018).

Table 5: Number of Accommodation Facilities and Beds in Mediterranean Countries (2018).

\begin{tabular}{|c|c|c|c|c|c|c|c|c|}
\hline \multirow[t]{2}{*}{ Ülkeler } & \multicolumn{2}{|c|}{ Otel ve Benzeri Tesisler } & \multicolumn{2}{|c|}{$\begin{array}{c}\text { Kısa Süreli Konaklama Tesisleri } \\
\text { (Kiralık evler) }\end{array}$} & \multicolumn{2}{|c|}{ Kamping } & \multicolumn{2}{|c|}{ Toplam } \\
\hline & Tesis Sayısı & Yatak Sayısı & Tesis Sayısı & Yatak Sayısı & Tesis Sayısı & Yatak Sayısı & Tesis Sayısı & Yatak Sayısı \\
\hline İtalya & 32.898 & 2.260 .893 & 180.963 & 1.700 .345 & 2.280 & 1.151 .959 & 216.141 & 5.113 .119 \\
\hline Fransa & 18.090 & 1.305 .914 & 3.554 & 980.642 & 8.018 & 2.825 .404 & 29.652 & 5.111 .960 \\
\hline İspanya & 19.657 & 1.940 .264 & 30.492 & 880.356 & 1.269 & 779.266 & 51.418 & 3.599 .886 \\
\hline Türkiye & 12.506 & 1.701 .383 & - & - & 71 & 9.688 & 12.557 & 1.713 .940 \\
\hline Yunanistan & 9.910 & 822.075 & 27.966 & 437.842 & 304 & 80.534 & 38.180 & 1.340 .451 \\
\hline Hırvatistan & 1.065 & 169.108 & 106.326 & 684.160 & 821 & 262.391 & 108.212 & 1.115 .659 \\
\hline Misır & 1.243 & 414.774 & - & - & - & - & 1.243 & 414.774 \\
\hline Fas & 4.055 & - & - & - & - & - & 5.534 & 261.256 \\
\hline Tunus & 868 & 237.618 & - & - & - & - & 868 & 237.618 \\
\hline İsrail & 419 & - & - & - & - & - & 17.096 & 136.022 \\
\hline Lübnan & 582 & - & - & - & - & - & 4.476 & 126.494 \\
\hline Cezayir & - & 119.155 & - & - & - & - & - & 119.155 \\
\hline Slovenya & 698 & 46.639 & 2.916 & 44.686 & 85 & 25.812 & 3.699 & 117.137 \\
\hline Kıbrıs & 947 & 111.413 & - & - & 2 & 988 & 949 & 112.401 \\
\hline KKTC & $(147)$ & $(25.241)$ & - & - & - & - & $(147)$ & $(25.241)$ \\
\hline GKRY & (800) & (86.252) & - & - & (2) & (988) & (802) & (87.213) \\
\hline Arnavutluk & 1.021 & 69.395 & 268 & 9.478 & 37 & 685 & 1.326 & 80.199 \\
\hline Malta & 194 & 43.522 & 17 & 1.717 & - & - & 211 & 45.239 \\
\hline Karadağ & 340 & 36.155 & 30 & 4.567 & 12 & 2.453 & 382 & 43.175 \\
\hline Bosna-Hersek & 668 & - & - & - & - & - & 668 & 37.092 \\
\hline Filistin* & 125 & 15.145 & - & - & - & - & 125 & 15.145 \\
\hline Monako & 12 & 5.104 & - & - & - & - & 12 & 5.104 \\
\hline Libya** & - & - & - & - & - & - & - & - \\
\hline Suriye** & - & - & - & - & - & - & - & - \\
\hline Akdeniz H. & 105.298 & 9.179 .402 & 352.532 & 4.743 .793 & 12.899 & 5.139 .180 & 492.749 & 19.745.376 \\
\hline
\end{tabular}

ilgi artacak; küresel 1sınmayla birlikte dağlardaki kayak merkezleri tehdit altında kalacak (sözgelimi Fransa'da dağlar 2050'de kar örtüsünü \%15-50 oranında kaybedecek); gelecek bize kanepeden seyahate çıkmak için hareketsiz sanal seyahat olanakları sunacak, öte yandan sanal gerçeklik ilham verici bir araç olarak seyahat arzusu uyandıracak; tatillerin demokratikleşmesinden demokratik turizme dönüşüm olacak (turistlerin artık uzmanlara ve profesyonellere güvenmediği yeni yatay yapılanma yoluyla akran topluluklara adapte olacaklar); turizm ve e-ticaret arasında uzlaşma olacak; robotlaşma ve yapay zekâ, yolculuklardan önce, sırasında ve sonrasında bilgilere nasıl erişeceğimizi tayin edecek, dil engelini tamamen ortadan kaldıracak (DGE, 2016).

Akdeniz ülkelerinde turizmin sürdürülebilir gelişimi için turizmin çeşitlendirilmesi ve ekoturizm, kültürel turizm, kırsal turizm vb. turizm türlerinin daha fazla ön plana çıkması gerekmektedir. Bu sayede Akdeniz destinasyonlarının denizkum-güneş üçlüsüne olan bağımlılığı azalabilir ve turizmde mevsimselliğin önüne geçilerek turizm tüm yıla yayılabilir. Fransa'nın Côte d'Azur bölgesinde fuar ve festivallerin yarattığı etki, bunun en güzel örneklerindendir (UNEP/MapPlan Bleu, 2009).

\subsection{Uluslararası Turist Hareketlerinde Akdeniz Ülkelerinin Gelecekteki Payı}

Akdeniz, bugün dünyada en fazla uluslararası turist kabul eden bölge durumundadır. Aynı zamanda dünya çağında ünlü destinasyonlara sahip ülkelerin birçoğu buradadır: Fransa, İspanya, İtalya, Türkiye, Yunanistan, Hırvatistan ve Misır. Akdeniz Havzası'ndaki uluslararası turist hareketleri için 2005 yılından 2025 yllını öngören bir projeksiyonda (PNUE/PAM, 2005, s.17), 2005'de uluslararası turist girişlerinde lider olan 4 ülkenin (Fransa, İspanya, İtalya, Türkiye) yine aynı sıralamada olacağı sonucuna ulaşılmıştır.

Dünya Turizm Örgütü'nün (UNWTO, 2011) sayısal tahmin modeline göre; 2030 yılında uluslararası turist sayısı 1.8 milyar kişiye ulaşacak, Avrupa'nın payı \%41'e gerileyecek, ancak yine de en çok turist kabul eden bölge olmaya devam edecektir. Bu kapsamda bir başka tespit, Avrupa içindeki alt bölgeler arasında 
Güney Avrupa/Akdeniz Bölgesi'nin 2030'da payının oldukça azalacağ 1 (2018'de \%20,7'den 2030'da \%14,6'ya), ancak birinci sırada olmayı koruyacağı yönündedir (Şekil 2). Bu alt bölgenin yalnızca Avrupa'daki Akdeniz ülkelerini kapsadığını hatırlatmak yerinde olacaktır.

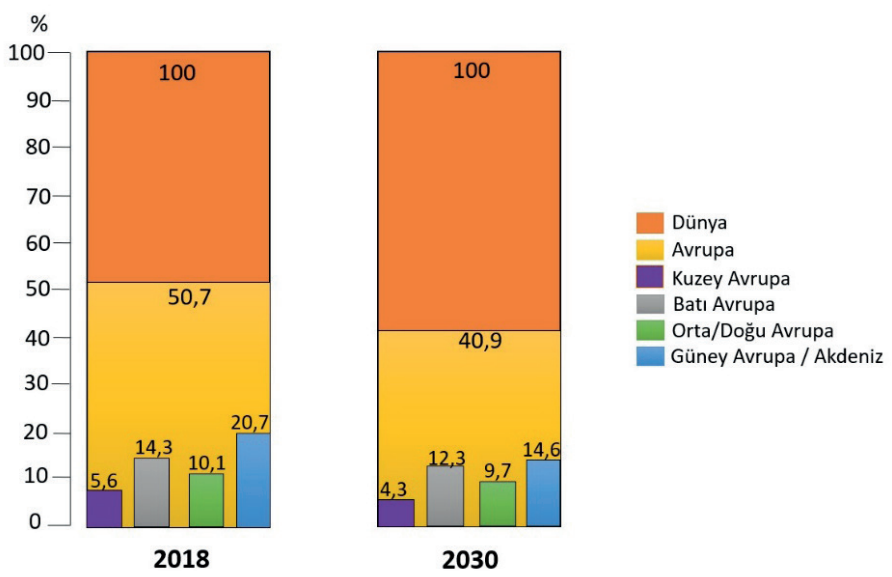

Şekil 2: Avrupa'da Alt Bölgelere Göre Uluslararası Turist Oranları ve 2030 Yılı Öngörüsü.

Figure 2: International Tourist Rates by Sub-Regions in Europe and the Projection for 2030.

Kaynak: UNWTO, 2011; 2019'dan yararlanılarak hazırlanmıștır.

Son elli yılda hem Avrupa'ya hem de Akdeniz Havzası'na varışların giderek azalması ve daha da azalacağının öngörülmesi, bu iki geleneksel büyük destinasyonun artık eskimiş olduğuna ve eski çekim gücünün kalmadığına bağlansa da, arka planda çok daha fazla etken yatmaktadır. Bu etkenlere; arz, talep ve yeni destinasyonlar olmak üzere üç yönden yaklaş1labilir. Akdeniz ülkelerinin dünya turizminde çok tanınmış olmaları ve bir anlamda belleklerde eskimesi nedeniyle ilgi görme düzeyi azalmakta, çağın gereklerine ve yeni turizm eğilimlerine uygun yenilik ve yaratıcılıkların yapılmaması da bunu körüklemektedir. Günümüz turist profilinde çok hızlı hareket, çok hızlı tüketim, sosyal medyaya ve dijital dünyaya bağl1lık, macera, mücadele, eğlence, spor, sağlık, kalite, korunmuşluk gibi kavramların geniş yer tutması, bu yöndeki beklentilerin karşılanmasını gerektirmektedir. Talebin bu dönüşümüne ayak uyduramayanların ülkelerin rekabet gücü azalmaktadır. Diğer taraftan dünyada az bilinen kültürlere olan ilginin artması ve beraberinde de bu tür yerlere ulaşımın kolaylaşması, bu destinasyonlarda hizmetlerin kalite ve çeşidinin artırılması, yeni destinasyonları tırmanışa geçirmiştir ki onların başında Asya-Pasifik gelmektedir. Nitekim bu bölgenin uluslararas1 turist hareketlerinden aldığ 1 pay 1990'da \%13'den 2018'de \%25'e yükselmiştir ve gelecekte de bu tırmanışını sürdürmesi beklenmektedir (UNWTO, 2019).

\subsection{Küresel Gelişmelerin Akdeniz Ülkeleri Turizmine Yansımaları ve Sorunlar}

Küreselleşen dünyada dolaşan sadece sermaye ve tüketim malları değildir. Tüm dünyayı dolaşan turistler de yenidünya düzeninin bir parçasıdır. Uluslararası turizme kapılarını açan bir ülke sadece turiste ve onun getirdiği dövize hoş geldin demez; fakat aynı zamanda çokuluslu turizm şirketleri ile birlikte gelen teknoloji, sermaye ve finansman ile dünya piyasasına ve tüketim merkezli batı kültürüne de kapılarını açar.

Avrupa Birliği (EU, 2012) Akdeniz turizmini bekleyen sorunları ve geleceğini etkileyecek konuları 2012 yılında şöyle saptamıştır: (i) küreselleşme, değişen pazarlar ve turizmin ekonomik etkilerini yönetebilme, (ii) iklim değişikliği ve sürdürülebilirlik arasında denge kurabilme, (iii) bilgi ekonomisinden yararlanabilme ve insan kaynaklarını güçlendirebilme. $\mathrm{Bu}$ maddelere 2012 yılından sonra daha birçokları eklenmiştir. Onlardan biri; 2019 yılı Aralık ayının sonlarında Çin'in Vuhan kentinde görülen COVID-19, hızla salgın hâle gelerek kısa sürede tüm dünyaya yayılmıştır. Bunun üzerine Dünya Sağlık Örgütü 30 Ocak 2020'de "Uluslararası Kamu Sağlığl Acil Durumu", 11 Mart'ta ise "Küresel Salgın" ilan etmiş ve birçok ulusal/uluslararası seyahat kısıtlamalarına gitmiştir. Salgınla birlikte Avrupa ve Güney Avrupa/Akdeniz Bölgesi, belki de salgının turizm üzerinde etkilerinin en fazla görüldüğü bölgelerin başında gelmiştir. İtalya, İspanya, Türkiye ve Fransa başta olmak üzere bütün ülkeleri derinden etkileyen salgın, turizm hareketliliğini durma noktasına getirmiştir. Nitekim Dünya Turizm Örgütü’nün (UNWTO, 2020a) yayımladığı rapora göre 2020 yılının ilk çeyreğinde uluslararası turizm \%22 oranında azalmış ve yıl sonunda bu oranın \%60-80 aralığında olması beklenmektedir. Mayıs 2020 itibariyle, Avrupa'daki toplam uluslararası turist kaybı toplam \%58'e ulaşmış ve en büyük kayıp toplam \%65 ile Güney Avrupa/Akdeniz bölgesinde gerçekleşmiştir. Akdeniz ülkelerinde 2020'nin ilk 5 ayında uluslararası turist oranlarındaki azalışta, Hırvatistan \%87, Yunanistan \%67, İsrail \%67, Türkiye \%66, İspanya \%64, İtalya \%53 oranlarını görmüştür (UNWTO, 2020b). Bu süreçte ülkeler, uluslararası turizme bağımlı olmanın ekonomik etkilerini yakından hissetmişler ve büyük oranda iç turizme yönelmişlerse de salgının yayılması ve yasaklar nedeniyle başarılı sonuçlar alınamamıştır. Önümüzdeki aylarda da salgının tüm ülkelerin turizmini çok yönlü etkilemeye (turist sayısı, gelir, istihdam, ulaşım, konaklama, yatırım vd.) devam edeceği öngörülmektedir.

Akdeniz ülkelerinde turizmin geleceğini etkileyecek gelişmelerden bir diğeri; son yıllarda yaşanan teknolojik 
yenilikler, internetin yaygınlaşması ve turizm endüstrisinde klasik işleyişin dışına çıkılarak "paylaşım ekonomisi platformlarının" giderek ağırlık kazanmasıdır. Milenyumla birlikte Web 2.0 sürecine geçiş, tüm dünyada internetin daha erişilebilir hâle gelmesi, kullanıcı tarafından oluşturulan içeriğin artması, sosyal medyanın birçok insanın hayatında önemli bir yer edinmesi, tüketim karşıtı ve çevre bilincine sahip her türlü paylaşımın artmasını sağlamıştır. $\mathrm{Bu}$ süreçte turistlerin tatil anlayışları ve beklentileri de değişmeye başlamıştır. Otantik olma, deneyimleme, keşfetme, yaratıc1lı, özgürlük "post-turist" kimliğinin merkezine oturmuştur. Ayrıca 1982-2000 y1lları arasında doğan Y kuşağı bireyleri ile 2000 yılı sonrası doğan Z kuşağı bireyleri, önceki nesillere kıyasla teknolojiyi kullanma ve paylaşma konusunda daha istekli olduklarından, turizmde farklı beklentiler içine girmişlerdir. Bu yeni akım, ulaşım ve konaklama başta olmak üzere turizmin tüm yapısında bir değişimi beraberinde getirmiştir. Airbnb, Couchsurfing, HomeExchange, Uber, BlaBlaCar vb. birçok ücretli ya da ücretsiz, kişiden kişiye ya da işletmeden kişiye faaliyet gösteren platformlar geleneksel turizm işletmeciliğinin yerini almaya başlamıştır. Örneğin, turistlere diledikleri destinasyonlarda, istedikleri nitelikte ve fiyatta kısa süreli konaklama olanağı sağlayan Airbnb, günümüzde 220 ülkede, 100.000 'den fazla kentte, 7 milyondan fazla liste içeren devasa bir yapıya bürünmüştür (Airbnb, 2020). Dünyada aktif Airbnb paylaşımlarının en yoğun olduğu bölgeler Kuzey Amerika ve Avrupa'dır. Avrupa, tüm Airbnb paylaşımlarının yaklaşık \%50'sini karşılamaktadır ve Barselona, Malaga, Valensiya, Atina, Beyrut, Tel Aviv, Antalya gibi Akdeniz kentlerinde sayı oldukça fazladır. Paylaşım ekonomisi platformlarının önlenemez yükselişi, sosyo-ekonomik birçok problemi de beraberinde getirdiği için birçok kent ya da kurum ve kuruluş, yasal düzenlemelerle bu paylaşım ağlarına kısıtlamalar getirmeye başlamış ya da tam tersi protokol imzalamak zorunda kalmışlardır (AMRF, 2019; Laurent, 2019). Önümüzdeki süreçte bu etkinin ve düzenlemelerin Akdeniz Havzası'nın kıyı destinasyonları ve kentleri kadar, kıyının ardülkesindeki kırsalda da yaygınlaşacağına kesin gözüyle bakılmaktadır.

Akdeniz ülkeleri, uzun yılların birikimi olarak birçok sorunla (çevresel kirlenme, başarısız yönetimler, sosyal eşitsizlik, kültürel bozulma ve ekonomik zorluklar vb.) iç içedir ve bunlar çözülmeden geleceğe taşındıkları takdirde, havzanın her türlü dengesi alt üst olacaktır. İşte bu sorunların büyüklüğü karşısında 1976 yılında, Akdeniz ülkelerinin sürdürülebilir kalkınma ve çevreden sorumlu karar vericileri ve aktörleri duyarlı kılmak amacıyla, gelecek için senaryolar üretmek üzere Fransa merkezli Plan Bleu/Mavi Plan Programı (https://planbleu.org) başlatılmıştır. Program bu kuruluş amaçları dışında şu görevleri de üstlenmiştir: iklim değişikliğine uyum sağlamak, yeşil ve mavi ekonomiye geçişi sağlamak, Akdeniz kaynaklarının uygun yönetimi için sosyo-ekonomik iç görüyü yerleştirmek $v d$. Programın başlangıcından bugüne geçen 44 sene içinde korumacılık ve yönetişim adına önemli iyileştirmeler yapılsa da sorunlar bitmiş değildir. Nitekim Plan Bleu adına 2017 yılında bir rapor hazırlayan Fosse ve Le Tellier (2017, s.17-18), Akdeniz'de turizm sektörünün güncel konuları ve sorunlarını 5 ana başlıkta (toplam 29 alt başlık-konu) toplayarak, bugünden yarına önemli risklere parmak basmışlardır. Ana başlıklar ve konulardan örnekler aşağıdaki gibidir:

1. Çevre: Ekosistemlerin ve doğal kaynakların bozulması, turizm tesisleri tarafindan tüketilmesi, bu tesislerin inşası ve kullanımı sırasında kıyı ekosistemlerinin değişmesi ve biyolojik çeşitliliğin kaybı vd.

2. Toplum: Eşitsizlikler, güvencesiz istihdam ve temel hakların garanti edilememesi; kayıt dışı, mevsimlik, vasıfsız, yarı zamanlı ve az ücretli kalitesiz işler; bölge yerelinin turizm yatırımlarındaki payının sınırlı kalması vd.

3. Ekonomi: Düşük kâr, zayıf rekabet gücü, krizlere karşı dayanıksızlık; kitle turizminin eskimesi; yabancı tur operatörlerine ve uluslararası pazarlara bağımlılık, beşeri sermaye gelişiminde ve donanımların modernizasyonunda yetersizlikler vd.

4. Kültür: Mirasin ve yerel kimliklerin kaybolma riski; turizm ürünleri ve donanımlarının küreselleşmesi ve benzer hâle gelmesi, yerel kimliğin standardizasyon sonucu bozulmas1, tarihsel ve kültürel değerlerin özgünlüğünün ve estetiğinin zayiflamas1 vd.

5. Yönetişim: İzleme eksikliği, yönetişim hataları ve etkisiz işbirlikleri; turizm faaliyetlerinin planlanması ve yönetiminde yerel toplumların katılım eksikliği, paydaşlar arasında işbirliği yokluğu ya da diyalogların yetersizliği vd.

\section{TARTIŞMA VE SONUÇ}

Turizm, tatillere "yer" sağlayıcı olarak mekânla doğrudan ilişkili bir faaliyettir. Dolayısıyla turizm, tükettiği alanların mekânsal biçimlenmesinin tek sorumlusudur (Ioannou, 2002, s.1). Akdeniz'de tarihsel süreç içinde askeri, ekonomik, ticari, sosyal ve kültürel hareketlilikler kadar turizm de kendine özgü bir yere ve öneme sahip olmuştur. Bölgedeki turizmle ilgili 
gelişmeler, tarihin dönüm noktaları temel alınarak belli dönemlere ayrıldığında; İlk Çağ'daki ziyaretlerin gezi, kültür, sanat, din, kehanet, spor, şifalı su ve eğlence amaçlı olduğu, katılanların Eski Yunanlılar, asil ve zengin Romalılar olarak öne çıktığı, bilim adamlarının da ilk gezginler arasında yer aldığı söylenebilir. Orta Çağ'ın ilk yarısında turizme dini hareketler damgasını vurmuş, Akdeniz dünyasında kutsal kentlere ziyaretler yapılmıştır. Rönesans döneminde gezginler ticaret, eğlence ve keşfetmek amaçlı seyahatler yapmışlardır.

16. ve 18. yüzyılları arasında prensler, soylular, devlet adamları, diplomatlar, sanatçılar, öğrenciler, bilim adamları ve zenginler tarafından gerçekleştirilen İngiltere çıkışlı Büyük Tur/ Grand Tour, modern turizmin erken formu ve öncüsü olmuştur. Özellikle Fransa'da Paris, Marsilya, Nice İsviçre'de Cenevre, Torino, Cenova, Roma, Napoli, Floransa ve Venedik başlica varış noktalarını oluşturmuş, özel rehberler görev yapmışlardır. 18. yüzyıl sonlarına doğru, Akdeniz kıyılarında sayfiye ve kaplıca kentleri (Nice ve Côte d'Azur gibi) kurulmaya başlamış, turistik seyahat büyük ölçüde varlıklı azınlık sınıfın ve eğitimlilerin etkinliği olmuştur.

19. yüzyılda sanayi devrimi ve demiryollarının yapımı, Avrupa'da turizm ve seyahatin yönünü tamamen değiştirmiş̧ir. Doğu Akdeniz'in romantizmi, bu kıyllardaki ülkelere bu yüzyılda büyük bir merak uyandırmıştır. Paris'ten başlayan Doğu Ekspresi tren yolculuğu, batı-doğu arasında turist akışının önemli bir itici gücü olmuştur. Yine bu yüzyılda İtalya, Sicilya ve Korsika'da kış aylarını geçirmek bir moda hâline gelmiştir. 19. yüzyılın ilk çeyreğinden 20. yüzyılın ortalarına kadar geçen süre, modern turizme giriş evresi olarak kabul edilmektedir. $\mathrm{Bu}$ dönemde turizm, otel, motel, ulaşım araçları ve yolları, plajlar, eğlence ve spor alanları, konaklama tesisleri ve tüm altyapısıyla büyük bir sektör hâline gelmiş ve en çarpıcı gelişmeler Akdeniz ülkelerinde yaşanmıştır. 1960'lı yıllar sonrasında turizm kitlesel hâle gelmiş, Fransa, İspanya ve İtalya, Akdeniz kitle turizminin yıldızları olmuşlardır.

Akdeniz ülkeleri geçmişte olduğu gibi bugün de uluslararası turizm hareketinin merkezi konumundadır. Akdeniz'in en büyük ülkesel destinasyonları Fransa, İspanya, İtalya ve Türkiye'dir, onları Yunanistan, Hirvatistan, Fas ve Misır izlemektedir. Bu sıralamada rol oynayan çok sayıda faktör vardır ve bunlar yıldan yıla değişmektedir. Anlaşılan odur ki Akdeniz dünyasında yalnızca eşsiz çekiciliklere sahip olmak artık yeterli değildir. Turistin beklentileri ve tatilden doyum sağlaması çok farklılaşmıştır. Ülkeler arasında rekabet gücünü etkileyen korumacılık, hizmet kalitesi ve güvenlik olarak ön plana çıkmaktadır. Belki onların da üstünde ekonomik ve politik faktörler hepsini kontrolü altında tutmaktadır. Önümüzdeki yıllarda turizmin talep ve hizmetler açısından gelişimini, dünyada barışın hüküm sürmesi ya da gerginliklerin çatışmaya dönüşmesi, ekonomik krizler, küresel iklim değişimi ve çevresel kirlilikler, teknolojik yenilikler derinden etkileyecektir. $\mathrm{Bu}$ durumda çoğu turistik destinasyon hayatta kalabilmenin mücadelesini verirken, diğerleri de kıyasıya bir rekabet ortamı içinde yer alacaklardır. Avrupa'nın tüm makro bölgeleri içinde Akdeniz Havzasi; coğrafi ve jeopolitik konumu nedeniyle dünyadaki gelişmelerden olumlu-olumsuz derecelerde en fazla etkilenen bölgelerden biri olması sıfatıyla, ülkelerarası barışçıl ilişkilere, destinasyon ve kriz yönetimine büyük önem vermesi gerekecektir.

Hakem Değerlendirmesi: Dış bağımsız.

Çıkar Çatışması: Yazarlar çıkar çatışması bildirmemiştir.

Finansal Destek: Yazarlar bu çalışma için finansal destek almadığını beyan etmiştir.

Peer-review: Externally peer-reviewed.

Conflict of Interest: The authors have no conflict of interest to declare.

Grant Support: The authors declared that this study has received no financial support.

\section{KAYNAKÇA/REFERENCES}

Airbnb. (2020). Fast Facts, https://news.airbnb.com/fast-facts/ Erişim Tarihi: 12.04 .2020

Akoğlan Kozak, M., Evren, S. ve Çakır, O. (2013). Tarihsel Süreç İçinde Turizm Paradigması, Anatolia Turizm Araştırmaları Dergisi, 24(1): 7-22.

AMRF. (2019). Airbnb et l'AMRF s'associent pour développer le tourisme dans la France rurale, https://news.airbnb.com/fr/airbnbet-lamrf-sassocient-pour-developper-le-tourisme-rural/_ Erişim tarihi: 25.06.2020

Arslan, A. (2014). 19. Yüzyıl Türkiye Gezi Rehberleri: John Murray Yayınları. III. Disiplinlerarası Turizm Araştırmaları Kongresi, 0405 Nisan 2014, Kuşadası, Aydın, Bildiri Kitabı, 151-163.

Atout France. (2016). Lettre de Veille Internationale - Eté 2016. http:// atout-france.fr/sites/default/files/imce/lettre_de_veille_ internationale ete 2016.pdf, Erişim tarihi: 03.09.2020.

Baykal, F. (1992). Akdeniz Havzası'nda uluslararası turizm hareketleri ve Türkiye. Turizm Yıllı̆̆l-1992, 29-40, Türkiye Kalkınma Bankası, Ankara.

Bozok, D. ve Köroğlu, A. (2007). Akdeniz ülkelerine yönelik uluslararas1 turizm hareketleri, Ticaret ve Turizm Eğitim Fakültesi Dergisi, 1, $146-157$.

Bramwell, B. (2004). Mass Tourism, Diversification and Sustainability in Southern Europe's Coastal Regions, In Bill Bramwell (ed.) Coastal Mass Tourism Diversification and Sustainable Development in Southern Europe (pp. 1-31) Channel View Publications. 
Chamailleurs, C. D. (2013). Le tourisme, son histoire et son evolution, http://cercledeschamailleurs.over-blog.com/article-le-tourismeson-histoire-et-son-evolution-121389628.html Erişim tarihi: 03.09.2020.

Coudert, E. (1996). Le littoral méditerranéen, un espace convoité. Aménagement et Nature, 121, 33-39.

Demir, E. (2017). Kentsel Kültürel Turizmde Ă̆ Toplumu ve Paylaşım Kültürünün Turizm Coğrafyast Yaklaşımıyla Değerlendirilmesi: İzmir Örneği. (Yüksek Lisans Tezi), Ege Üniversitesi, İzmir.

DGE. (2016). Tourisme 2050: Quelques Idées Pour le Future. Direction Générale des Entreprises, Ministère de L'économie, de L'industrie et du Numérique, France.

Encyclopædia Britannica. (2019). Yugoslavia former federated nation (1929-2003), https://www.britannica.com/place/Yugoslavia-former -federated-nation-1929-2003 Erişim tarihi: 04.09.2020

Eralp, Z. (1983). Genel Turizm. Ankara Üniversitesi Basın-Yayın Yüksek Okulu Yayınları: 3, Ankara.

European Union. (2012). Sustainable Tourism in the Mediterranean. Aston Centre for Europe, Aston University. https:/cor.europa.eu/ en/engage/studies/Documents/sustainable-tourism-mediterranean/ sustainable-tourism-mediterranean.pdf Erişim tarihi: 17.08.2020

Eurostat. (2020). Tourism statistics - Annual results for the accommodation sector, https:/ec.europa.eu/eurostat/statisticsexplained/pdfscache/37341.pdf Erişim tarihi: 17.08.2020

Fosse, J. ve Le Tellier, J. (2017). Tourisme durable en Méditerranée : état des lieux et orientations stratégiques, Cahier 17, Plan Bleu. Valbonne.

Harita Genel Müdürlüğü. (2020). Avrupa Fiziki Haritas1, https://www. harita.gov.tr/urun-209-avrupa-fiziki-haritasi-.html Erişim Tarihi: 15.08 .2020

Horner, B. (2016). Nice d'autrefois et Nice d'aujourd'hui, https://edito. seloger.com/lifestyle/visite-privee/nice-d-autrefois-et-nice-daujourd-hui-article-9283.html Erişim Tarihi: 01.09.2020

Gyr, U. (2010). The History of Tourism: Structures on the Path to Modernity European History Online (EGO). http://ieg-ego.eu/en/ threads/europe-on-the-road/the-history-of-tourism Erişim tarihi: 17.08.2020

INSTAT.(2019).Albania Tourism SurveyAccommodation establishments, http://www.instat.gov.al/media/7332/tourism-surveyaccommodation-establishments-2019.pdf Erişim tarihi: 17.08.2020

Ioannou, B. (2002). Tourist Development Impacts on the Spatial Transformation of the Greek Islands. The Case Study of Kos Insular Area, ERSA Conference Papers, European Regional Science Association, https://econpapers.repec.org/paper/wiwwiwrsa/ersa02 p130.htm Erişim tarihi: 13.08.2020.

Işık, Ş. ve Zoğal, V. (2017). Turizm kentleşmesi kavramı: Antalya örneği, Ege Coğrafya Dergisi, 26(2), 71-94.

Knoema. (2018). World Tourism Statistics, Key Indicators, 1995-2018 https://knoema.com/WTODB2017/world-tourism-statistics-keyindicators-1995-2018?location=1001600-reunion Erişim tarihi: 17.08.2020
KKTC Turizm Planlama Dairesi. (2018). Turizm İstatistikleri, http:// turizmplanlama.gov.ct.tr/2018-İstatistikleri Erișim tarihi: 17.08.2020

Koshar, R. (2002). Seeing, Traveling, and Consuming: An Introduction. In Koshar, R. (Ed.), Histories of Leisure. (pp. 1-24), Oxford International Publishers, Oxford.

Kozak, N., Kozak, M.A. ve Kozak, M. (2001). Genel Turizm. İlkelerKavramlar. Detay Yayınc1lık, Ankara.

Laurent, A. (2019). Tourisme: Comment Airbnb s'implante dans le monde rural https://www.challenges.fr/entreprise/tourisme/ tourisme-comment-airbnb-s-implante-dans-le-monde-rural_ 644277, Erişim tarihi: 16.03.2020.

Lozato-Giotart, J. P. (1990). Méditerranée et tourisme. Paris: Masson S.A.

Löschburg, W. (1998). Seyahatin Kültür Tarihi (Jasmin Traub, Çev.). Dost Kitabevi, Ankara.

Magnan, A. (2009). Le Tourisme Littoral en Méditerranée. Tendances et Perspectives Face au Changement Climatique. Idées Pour le Debats. Institut du Développement Durable et des Relations Internationales (IDDRI), No: 4, 1-46.

Manera, C. ve Morey, A. (2016). The growth of mass tourism in the Mediterranean, 1950-2010, IOSR Journal of Economics and Finance (IOSR-JEF), 7(4), 84-91.

Mullins, P. (1991). Tourism urbanization. International Journal of Urban and Regional Research, 15(3): 591-597.

Owen, E. (2019). Grand Tours and a Giveaway, https://austenauthors. net/grand-tours-and-a-giveaway/ Erişim Tarihi: 01.09.2020.

Özgüç, N. (2017). Turizm Coğrafyası Özellikler ve Bölgeler. Çantay Kitabevi, İstanbul.

Plan Bleu. (2016). Tourism. Economic activities and sustainable development. Building the Mediterranean future together, https:// planbleu.org/sites/default/files/publications/note32_en.pdf Erişim Tarihi: 01.09.2020.

PNUE/PAM. (2005). Dossier sur Le Tourisme et le Développement Durable en Méditerranée. MAP Technical Report Series No. 159, Athènes, Grèce.

Rosenberg, M. (2017). Grand Tour of Europe. The Travels of 17th \& 18th Century Twenty-Somethings, https://www.thoughtco.com/ grand-tour-of-europe-1435014, Erişim Tarihi: 08.09.2017.

Rovira Soto, M.T. ve Anton Clavé, S. (2017). Second homes and urban landscape patterns in Mediterranean coastal tourism destinations. Land Use Policy, 68, 117-132.

Rovira Soto, M.T. ve Anton Clavé, S. (2018). The role of second homes in a Mediterranean coastal mass tourism destinations: An evolutionary perpective, In Hall, C.M ve Müller, D.K. (eds.) The Routledge Handbook of Second Home Tourism and Mobilities, (pp. 27-38).

Sarı Çallı, D. (2015). Uluslararası Seyahatlerin Tarihi Gelişimi ve Son Seyahat Trendleri Doğrultusunda Türkiye'nin Konumu, Turizm ve Araştırma Dergisi, 4(1), 4-28.

Selwyn, T. (2000). The De-Mediterraneanisation of the Mediterranean. Current Issues in Tourism, 3(3), 226-245. 
T.C. Kültür ve Turizm Bakanlığı. (2020). Tesis İstatistikleri, https:// yigm.ktb.gov.tr/TR-201131/tesis-istatistikleri.html Erişim tarihi: 17.08.2020

Terkenli, T. S., Bellas, M. L. ve Jenkins, L. D. (2007). Tourism Impacts on Local Life: Socio-Cultural Continuity and Change in Crete, Ege Coğrafya Dergisi, 16, 37-52.

Tixeront, J. (1969). Le bilan hydrologique de la Mer Noire et de la Mer Mediterranée. Bulletin of the International Association of Scientific Hydrology, 14(4), 61-69.

Toskay, T. (1990). Turizm. Turizm Olayına Genel Yaklaşım, Der Yayınları, İstanbul.

Tutan, E. ve Başol, S. (2014). Antik Çağda Bir Turizm Destinasyonu: Delphoi. Disiplinlerarası Turizm Araştırmaları Kongresi, 04-05 Nisan 2014, Kuşadası, Aydın, Bildiri Kitabı, 384-387.

UNEP/MAP-Plan Bleu. (2009). State of the Environment and Development in the Mediterranean, Athens. https://planbleu.org/sites/default/files/ publications/soed2009_en.pdf Erişim Tarihi: 01.09.2020

UNWTO. (2011). Tourism Towards 2030, Global Overview. https:// www.e-unwto.org/doi/epdf/10.18111/9789284414024 Erişim tarihi: 17.08.2020
UNWTO. (2017). Tourism Highlights 2017 Edition. https://www.e-unwto. org/doi/pdf/10.18111/9789284419029 Erişim tarihi: 17.08.2020

UNWTO. (2019). International Tourism Highlights 2019 Edition. https://www.e-unwto.org/doi/pdf/10.18111/9789284421152 Erişim tarihi: 17.08 .2020

UNWTO. (2020a). International tourist numbers, 2020 from https:// www.unwto.org/news/covid-19-international-tourist-numberscould-fall-60-80-in-2020. Erişim tarihi: 17.08.2020

UNWTO. (2020b). International Tourism and COVID-19, https://www. unwto.org/international-tourism-and-covid-19 Erişim tarihi: 17.08.2020

Urry, J. (2009). Turist Bakışı, (E. Tataroğlu; İ. Yıldız, Çev.), Bilgesu Yayınc1l1k, İstanbul.

Yıldız, Z. (2011). Turizmin Sektörünün Gelişimi ve İstihdam Üzerindeki Etkisi. Süleyman Demirel Üniversitesi. Vizyoner Dergisi, 3(5), 5471.

Zuelow, E. (2015). A History of Modern Tourism. Macmillan Education, London. 